\title{
Serological Assay and Genotyping of Hepatitis C Virus in Infected Patients in Zanjan Province
}

\author{
Abdolreza Esmaeilzadeh ${ }^{1,2,}$; Maryam Erfanmanesh ${ }^{3}$; Sousan Ghasemi ${ }^{4}$; Farzaneh \\ Mohammadi $^{1}$ \\ ${ }^{1}$ Department of Immunolory, Faculty of Medicine, Zanjan University of Medical Sciences, Zanjan, IR Iran \\ ${ }^{2}$ Cancer Gene Therapy Research Center, Faculty of Medicine, Zanjan University of Medical Sciences, Zanjan, IR Iran \\ 3 Young Researchers Club, Zanjan Branch, Islamic Azad University, Zanjan, IR Iran \\ 4 Medical Laboratory, Shaheed Beheshti General Hospital, Zanjan University of Medical Sciences, Zanjan, IR Iran \\ ${ }^{*}$ Corresponding Author: Abdolreza Esmaeilzadeh, Department of Immunology, Zanjan University of Medical Sciences, Mahdavi Blvd., Zanjan, IR Iran. Tel: +98-2433440301, Fax: +98- \\ 2433449553, E-mail:a46reza@zums.ac.ir
}

Received: January 1, 2014; Revised: February 22, 2014; Accepted: May 23, 2014

Background: Hepatitis C Virus (HCV), a public health problem, is an enveloped, single-stranded RNA virus and a member of the Hepacivirus genus of the Flaviviridae family. Liver cancer, cirrhosis, and end-stage liver are the outcomes of chronic infection with HCV. HCV isolates show significant heterogeneity in genetics around the world. Therefore, determining HCV genotypes is a vital step in determining prognosis and planning therapeutic strategies.

Objectives: As distribution of HCV genotypes is different in various geographical regions and HCV genotyping of patients has not been investigated in Zanjan City, this study was designed for the first time, to determine HCV genotypes in the region and to promote the impact of the treatment.

Materials and Methods: Serum samples of 136 patients were collected and analyzed for anti-HCV antibodies using ELISA (The enzymelinked immunosorbent assay) method. Then, positive samples were exposed to RT-PCR, which was performed under standard condition. Afterwards, they investigated for genotyping using allele-specific PCR(AS-PCR), and HCV genotype 2.0 line probe assay(LiPA).

Results: Samples indicated 216 bp bands on $2 \%$ agarose gel. Analyses of the results demonstrated that the most dominant subtype was 3a with frequency of $38.26 \%$ in Zanjan Province followed by subtypes of $1 \mathrm{~b}, 1 \mathrm{a}, 2$, and 4 with frequencies of $25.73 \%, 22.05 \%, 5.14 \%$, and $4.41 \%$, respectively. The frequency of unknown HCV genotypes was $4.41 \%$.

Conclusions: According to the results, it was found that HCV high prevalent genotype in Zanjan is subtype 3a. Analysis of the results provides identification of certain HCV genotypes, and these valuable findings could affect the type and duration of the treatment.

Keywords:Anti-HCV Antibody; Hepatitis C Virus; Genotype; RT-PCR; AS-PCR

\section{Background}

Hepatitis C Virus (HCV), a worldwide blood borne infection with a global importance, is a significant cause of hepatic diseases, cirrhosis and hepatocellular carcinoma, after hepatitis B which its screening was introduced in blood banking laboratory methods (1-5). Chronic infection with HCV is a major cause of liver cancer, cirrhosis and end-stage liver in the world (6-8). It has been estimated that more than 170 million people are infected worldwide, and approximately 280000 deaths are attributed to chronic hepatitis $\mathrm{C}$ virus (HCV) infection each year (9). In the future prospect, deaths caused by HCV infection will be tripled over the next 20 years, especially in the developing countries (10). The HCV is an enveloped, single-stranded RNA virus and a member of the Hepacivirus genus of the Flaviviridae family (11).

The heterogeneous rate varies significantly in different areas $(12,13)$. Analysis of the different HCV genomic sequences has ascertained that the virus nucleotide se- quence can be different as much as 30\% (14). HCV virus has been divided into seven major genotypes (HCV-1 to HCV-7) (15). Also, each genotype is divided into multiple subtypes (e.g. 1a, 1b, etc.) These genotypes have different distributions in different geographical areas $(16,17)$. Since the genotype is a critical baseline predictor of the response to HCV antiviral therapy, determination of such a genotype is very important $(8,18)$.

Genotyping is necessary to predict the response rate and duration of the treatment $(10,19)$. By improving HCV therapy, HCV genotyping has become very useful, because the patients who need more aggressive management are helped for screening (20). Prevalence and incidence of the virus vary depending on the area of conflict $(17,21)$. Iran is located in the Middle-East. The rate of HCV infection in Iran is high for its geographical situation and huge immigration from Afghanistan and Iraq (5). Recent findings have shown that genotyping

Copyright (C) 2014, Kowsar;; Published by Kowsar. This is an open-access article distributed under the terms of the Creative Commons Attribution-NonCommercial 4.0 International License (http://creativecommons.org/licenses/by-nc/4.0/) which permits copy and redistribute the material just in noncommercial usages, provided the original work is properly cited. 
pattern in Iranian patients is comparable with Western Europe and North America, which constitutes genotypes 1 and 3. Despite the similarity of the distribution, these genotypes vary in different areas (22). Given the abovementioned findings, HCV genotyping in each region is of great importance; nonetheless, this study has not been performed in Zanjan, a province in North West of Iran. In this research, we evaluated the genotypes of the HCV in Zanjan. Identifying the most common type of genotype can help these patients. Not only the cost of the treatment can be minimized, but also the length of the treatment can be optimized.

\section{Objectives}

The purpose of this study was to offer an applicable prospect in the therapeutic context by identifying HCV genotypes in Zanjan Province, the Northwest of Iran.

\section{Materials and Methods}

\subsection{Serological Assay}

From 2007 to 2013, out of the patients who referred to the Clinical Laboratory for investigating anti-HCV antibodies, 136 patients with positive results were selected using anti HCV antibody ELISA kit (4th generation) (Anti HCV ELISA, DIAsource, Belgium) for further investigations.

\subsection{Molecular Assay}

About $5 \mathrm{~mL}$ of plasma (EDTA) for blood samples was stored in $-20^{\circ} \mathrm{C}$ for the following procedures. RNA was extracted under standard conditions using CinnaGen Diagnostic kit (CinnaGen Company, Tehran, Iran). In brief, cDNA was synthesized as the template for PCR reactions in the first round of PCR. Reagents with final volume of $45 \mu \mathrm{L}$ added to each tube on ice, containing $39 \mu \mathrm{L}$ Mix I, 1 $\mu \mathrm{L}$ RT Enzyme, $0.3 \mu \mathrm{L}$ Taq DNA Polymerase, and $40 \mu \mathrm{L}$ Mineral oil. After mixing well, RNA tubes were placed at $95^{\circ} \mathrm{C}$ for one minute, then placed on ice. Five microliter RNA of each patient, positive control and DEPC (Diethylpyrocarbonate) water were added to each tube for patients, positive and negative control, respectively. The mixture was centrifuged for 3-5 $\mathrm{s}$ and then placed on a cycle of $42^{\circ} \mathrm{C}$ for $20 \mathrm{~min}, 94^{\circ} \mathrm{C}$ for $2 \mathrm{~min}, 60^{\circ} \mathrm{C}$ for $40 \mathrm{~s}$ and $72^{\circ} \mathrm{C}$ for $40 \mathrm{~s}$. Next step comprised 20 cycles of $93^{\circ} \mathrm{C}$ for $40 \mathrm{~s}$, $60^{\circ} \mathrm{C}$ for $40 \mathrm{~s}, 72^{\circ} \mathrm{C}$ for $40 \mathrm{~s}$ based on the manufacturer's instructions. The second PCR round included the expected fragment $216 \mathrm{bp}$ amplification under the condition mentioned in the kit, including 35 cycles of $93^{\circ} \mathrm{C}$ for 40 $\mathrm{s}, 60{ }^{\circ} \mathrm{C}$ for $40 \mathrm{~s}$ and $72^{\circ} \mathrm{C}$ for $40 \mathrm{~s}$ (Flex cycler-Germany). Final 216 bp of PCR product was diagnosed using agarose gel electrophoresis detection system on a $2 \%$ agarose gel. The samples were evaluated for HCV genotyping by using allele-specific PCR (AS-PCR) (23), and HCV genotype 2.0 line probe assay (LiPA) (Versant HCV Genotype 2.0 Assay [LiPA], Siemens, Germany).

\section{Results}

Result analysis of gel electrophoresis on PCR products, indicated a $216 \mathrm{bp}$ band for each positive sample as shown in Figure 1. Genotyping results demonstrated that subtype 3a (38.26\%) was the most prevalent HCV type in Zanjan. Prevalence of subtypes 1b, 1a, 2, and 4 were $25.73 \%$, $22.05 \%, 5.14 \%$, and $4.41 \%$, respectively. Also, the frequency for unknown genotypes was $4.41 \%$.

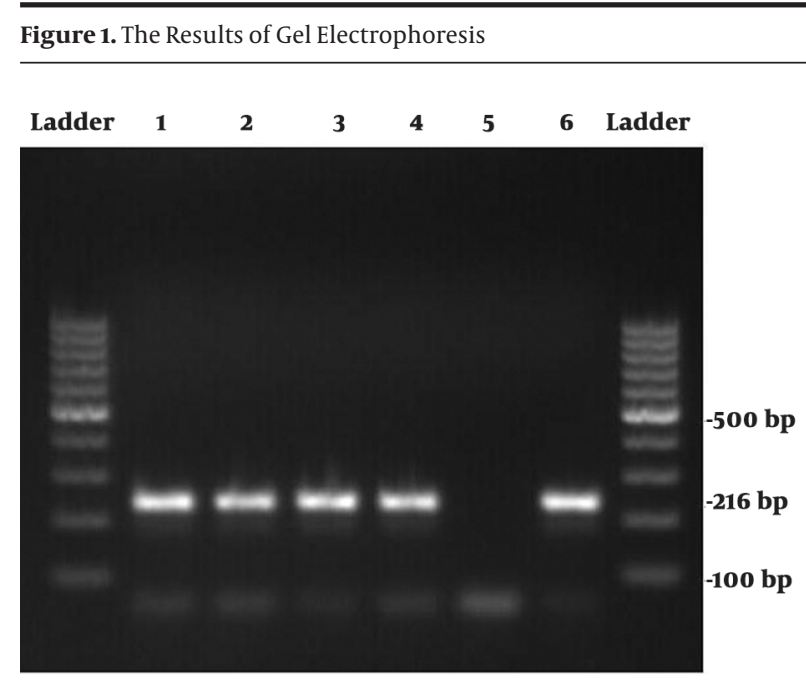

1-4, Four HCV positive patients; 5, Negative Control; 6, Positive Control.

\section{Discussion}

Genotyping of HCV has been regarded as a fundamental factor for treatment, prognosis, and prediction in clinical management (24), so that to begin the treatment and then follow up are in accordance with the virus genotype (25). The length of the therapy is also influenced by genotype (14). Recent studies have shown that the distribution of HCV genotypes varies in different geographical regions. Thus, determination of the predominant and less prevalent subtypes of HCV in various areas has a fundamental role. The interest for identifying HCV genotypes is increasing worldwide (25). This study was the first report of HCV genotypes prevalence in Zanjan (the Northwest of Iran). This study analyzed $136 \mathrm{HCV}$ positive samples for genotyping in the region. The results indicated that subtype $3 a$ with the frequency of $38.26 \%$ was the most current subtype in Zanjan.

This finding was consistent with a recent study performed in Tehran (a city near Zanjan) (22). It was also comparable with the obtained results reported (25) from Azerbaijani patients (in West Azerbaijan, Northwest of Iran) with established chronic hepatitis $\mathrm{C}$, who referred to some hospitals in Tehran (26). This similarity may be due to the proximity of Zanjan with these cities. A study in Shiraz, a city in Southern part of Iran estimated the prevalence of HCV genotype to be similar in the case of 3a type (8). Meanwhile, another comprehensive investigation 
performed in Tehran with a wide range of infected patients referring from all over the country has introduced subtype 1a as the most prevalent subtype in Iran (27).

Additionally, in a study in Isfahan (Iran) and on the bases of other reports, high prevalence of subtypes 3a and 1a and very low frequency of genotype 2 in Iran was demonstrated, which is different from Europe, USA, and even some parts of Asia (28). HCV subtypes 3a and 1a were determined in the hemodialysis patients living in Tehran as the prevalent subtypes (29). This finding is in contrast with global HCV genotypes prevalence (30) and the high frequency of genotype HCV 1a/1b in addition to HCV 4 and $\mathrm{HCV}$ 2/2a plus HCV 4 in hemodialysis patients living in the neighboring countries such as Bahrain and Saudi Arabia (31), which have sea borders with Khuzestan Province in Ahvaz. In addition, evaluation of chronic hepatic patients indicated 1a as the most prevalent subtype in Hormozgan (32).

On the whole, genotype 3 was more prevalent in regions such as India, Pakistan, and Southern Asia (33-35). In both Saudi Arabia and Egypt, genotype 4 was the predominant genotype (25). In most parts of China, subtype $1 \mathrm{~b}$ followed by $2 \mathrm{a}$ was found with high prevalence (36, 37). In a study in Chile (among blood donors), subtype $1 \mathrm{~b}$ with the frequency of $46 \%$ was the dominant type $(38,39)$. A research in central Italy was reported genotype 4 as the prevalent genotype (20). Gonzaga RM et al. investigated the distribution of hepatitis $C$ virus genotypes in seropositive patients in Brazil in 2008 (40). The prevalence of different HCV genotypes in the world are as follows: subtype 1a is mostly reported in North America and Europe. In Southern and Eastern Europe, Japan, and North Africa, the mostly reported subtype is $1 \mathrm{~b}$. Subtype $2 \mathrm{c}$ is common in Northern Italy. Encountering subtype 3a from South East Asia in Europe and the USA may be transmitted by travelers. Subtype 3a may be transmitted from South East Asia in Europe and the USA by travelers. Genotype 4 is highly common in Arab countries except Jordan while in Turkey and Israel genotype 1 were prevalent. Genotype 5 is highly common in South Africa. Genotype 6a is restricted to Hong Kong and Vietnam (41).

In conclusion, paying attention to high prevalence of a certain HCV genotype is essential in remedial terms of HCV. It could affect the therapeutic methods and duration. Determining HCV genotypes could increase the chance of successful treatment. To obtain more precise information regarding the genotype of this virus, we recommend larger study population of patients.

\section{Acknowledgements}

The authors would like to thank Zanjan Noor Clinical Laboratory for providing the samples and lab facilities and also Keivan, Bahar, and Noor laboratories in Tehran for their services such as providing genotyping results of some patients. It is necessary to appreciate all the staff of the laboratories for their help and sincere cooperation.

\section{Authors' Contributions}

Abdolreza Esmaeilzadeh designed and supervised the project and professionally edited the manuscript. Erfanmanesh, Sousan Ghasemi, and Farzaneh Mohammadi contributed in writing the article and collecting the data.

\section{Funding/support}

The samples and lab facilities have been provided by Zanjan Noor Clinical Laboratory.

\section{References}

1. Aalaei-Andabili SH, Behnava B, Salimi S, Sharafi H, Alavian SM Mysterious Linkages Between Hepatitis C Virus Genotypes, Interleukin-28B Genotypes and Viral Clearance- A Meta-Analysis. Hepat Mon. 2014;14(3)

2. Lavanchy D. Evolving epidemiology of hepatitis C virus. Clin Microbiol Infect. 2011;17(2):107-15.

3. Martin NK, Vickerman P, Foster GR, Hutchinson SJ, Goldberg DJ, Hickman M. Can antiviral therapy for hepatitis $C$ reduce the prevalence of HCV among injecting drug user populations? A modeling analysis of its prevention utility. J Hepatol. 2011;54(6):1137-44.

4. Lauer GM, Walker BD. Hepatitis C virus infection. $N$ Engl J Med. 2001;345(1):41-52.

5. Alavian SM, Adibi P, Zali MR. Hepatitis $C$ virus in Iran: Epidemiology of an emerging infection. Arch Iranian Med. 2005;8(2):84-90.

6. Piluso A, Giannini C, Fognani E, Gragnani L, Caini P, Monti M, et al. Value of IL28B genotyping in patients with HCV-related mixed cryoglobulinemia: results of a large, prospective study. J Viral Hepat. 2013;20(4):e107-14.

7. Aleman S, Rahbin N, Weiland O, Davidsdottir L, Hedenstierna M, Rose N, et al. A risk for hepatocellular carcinoma persists longterm after sustained virologic response in patients with hepatitis C-associated liver cirrhosis. Clin Infect Dis. 2013;57(2):230-6.

8. Ziyaeyan M, Alborzi A, Jamalidoust M, Badiee P, Moeini M, Kadivar A. Prevalence of hepatitis $C$ virus genotypes in chronic infected patients, southern Iran.Jundishapur JMicrobiol. 2011;4(3):141-6.

9. Farnik H, Mihm U, Zeuzem S. Optimal therapy in genotype 1 patients. Liver Int. 2009;29 Suppl 1:23-30.

10. Daw MA, Elasifer HA, Dau AA, Agnan M. The role of hepatitis C virus genotyping in evaluating the efficacy of INF-based therapy used in treating hepatitis C infected patients in Libya. Virol Discov. 2013;1(3):1-8.

11. Abuelhassan W. Hepatitis $C$ virus infection in 2012 and beyond. South Afr J Epidemiol Infect. 2012;27(3):93-7.

12. Kamal SM. Hepatitis C genotype 4 therapy: increasing options and improving outcomes. Liver Int. 2009;29 Suppl 1:39-48.

13. Ansar MM, Kooloobandi A. Prevalence of hepatitis $C$ virus infection in thalassemia and haemodialysis patients in north IranRasht. JViral Hepat. 2002;9(5):390-2.

14. Tajbakhsh E, Dosti A, Tajbakhsh S, Momeni M, Tajbakhsh F. Determination of hepatitis $C$ virus genotypes among HCV positive patients in Shahrekord, Iran. Afr J Microbiol Res. 2011;5(32):5910-5.

15. Smith DB, Bukh J, Kuiken C, Muerhoff AS, Rice CM, Stapleton JT, et al. Expanded classification of hepatitis $C$ virus into 7 genotypes and 67 subtypes: updated criteria and genotype assignment web resource. Hepatology. 2014;59(1):318-27.

16. Doerrbecker J, Meuleman P, Kang J, Riebesehl N, Wilhelm C, Friesland M, et al. Thermostability of seven hepatitis $C$ virus genotypes in vitro and in vivo. J Viral Hepat. 2013;20(7):478-85.

17. Shawa IT, Hopkins M. Evaluation of Hepatitis C Virus Genotyping Protocols for Use in a Diagnostic Setting. Int J Med Res. 2013;1(1):2-7.

18. Sam SS, Steinmetz HB, Tsongalis GJ, Tafe LJ, Lefferts JA. Validation of a solid-phase electrochemical array for genotyping hepatitis $\mathrm{C}$ virus. Exp Mol Pathol. 2013;95(1):18-22.

19. Gonzalez V, Gomes-Fernandes M, Bascunana E, Casanovas S, Salu- 
des V, Jordana-Lluch E, et al. Accuracy of a commercially available assay for HCV genotyping and subtyping in the clinical practice. JClin Virol. 2013;58(1):249-53.

20. Cenci M, Massi M, Alderisio M, De Soccio G, Recchia O. Prevalence of hepatitis $\mathrm{C}$ virus (HCV) genotypes and increase of type 4 in central Italy: an update and report of a new method of HCV genotyping. Anticancer Res. 2007;27(2):1219-22.

21. Zein NN. Clinical significance of hepatitis C virus genotypes. Clin Microbiol Rev. 2000;13(2):223-35.

22. Hajia M, Amirzargar A, Khedmat H, Shahrokhi N, Farzanehkhah M, Ghorishi S, et al. Genotyping Pattern among Iranian HCV Positive Patients. Iran J Public Health. 2010;39(2):39-44.

23. Bae AS, Ku KS, Miller MD, Mo H, Svarovskaia ES. Allele-specific real-time PCR system for detection of subpopulations of genotype $1 \mathrm{a}$ and $1 \mathrm{~b}$ hepatitis C NS5B Y448H mutant viruses in clinical samples. J Clin Microbiol. 2011;49(9):3168-74.

24. Nakatani SM, Santos CA, Riediger IN, Krieger MA, Duarte CA, do Carmo Debur M, et al. Comparative performance evaluation of hepatitis $C$ virus genotyping based on the 5 ' untranslated region versus partial sequencing of the NS5B region of brazilian patients with chronic hepatitis C. Virol J. 2011;8:459.

25. MirDavood O, Khadem AMH. Hepatitis c virus genotyping by melting curve analysis in west azerbaijan, northwest of IRAN Hepat Mon. 2009;9(2):133-6.

26. Bokharaei-Salim F, Keyvani H, Monavari SH, Alavian SM, Fakhim $S$, Nasseri S. Distribution of hepatitis C virus genotypes among azerbaijani patients in capital city of iran-tehran. Hepat Mon. 2013;13(9).

27. Jahanbakhsh Sefidi F, Keyvani H, Monavari SH, Alavian SM, Fakhim S, Bokharaei-Salim F. Distribution of hepatitis $C$ virus genotypes in Iranian chronic infected patients. Hepat Mon. 2013;13(1).

28. Zarkesh Esfahani SH, Kardi MT, Edalati M. Hepatitis C virus genotype frequency in Isfahan province of Iran: a descriptive crosssectional study. Virol J. 2010;7(69):1-6.

29. Hosseini-Moghaddam SM, Keyvani H, Kasiri H, Kazemeyni SM, Basiri A, Aghel N, et al. Distribution of hepatitis $C$ virus genotypes among hemodialysis patients in Tehran--a multicenter study. $J$ Med Virol. 2006;78(5):569-73.

30. Nguyen MH, Keeffe EB. Epidemiology and treatment outcomes of patients with chronic hepatitis $C$ and genotypes 4 to 9 . Rev Gastroenterol Disord. 2004;4 Suppl 1:S14-21.

31. Qadi AA, Tamim H, Ameen G, Bu-Ali A, Al-Arrayed S, Fawaz NA, et al. Hepatitis $B$ and hepatitis $C$ virus prevalence among dialysis patients in Bahrain and Saudi Arabia: a survey by serologic and molecular methods. Am J Infect Control. 2004;32(8):493-5.

32. Mousavi SF, Moosavy SH, Alavian SM, Eghbali H, Mahboobi H Distribution of hepatitis $\mathrm{C}$ virus genotypes among patients with hepatitis $C$ virus infection in hormozgan, iran. Hepat Mon. 2013;13(12).

33. Akhtar S, Moatter T, Azam SI, Rahbar MH, Adil S. Prevalence and risk factors for intrafamilial transmission of hepatitis $C$ virus in Karachi, Pakistan. J Viral Hepat. 2002;9(4):309-14.

34. Lole KS, Jha JA, Shrotri SP, Tandon BN, Prasad VG, Arankalle VA. Comparison of hepatitis $C$ virus genotyping by 5 ' noncoding region- and core-based reverse transcriptase PCR assay with sequencing and use of the assay for determining subtype distribution in India. J Clin Microbiol. 2003;41(11):5240-4.

35. Singh S, Malhotra V, Sarin SK. Distribution of hepatitis C virus genotypes in patients with chronic hepatitis $C$ infection in India. Indian J Med Res. 2004;119(4):145-8.

36. Zhang L, Chen Z, Cao Y, Yu J, Li G, Yu W, et al. Molecular characterization of human immunodeficiency virus type 1 and hepatitis $C$ virus in paid blood donors and injection drug users in china. $J$ Virol. 2004;78(24):13591-9.

37. Lu L, Nakano T, He Y, Fu Y, Hagedorn CH, Robertson BH. Hepatitis $C$ virus genotype distribution in China: predominance of closely related subtype $1 \mathrm{~b}$ isolates and existence of new genotype 6 variants. J Med Virol. 2005;75(4):538-49.

38. Mohsen AH, Trent HCVSG. The epidemiology of hepatitis $C$ in a UK health regional population of 5.12 million. Gut. 2001;48(5):707-13.

39. Thomson BJ, Finch RG. Hepatitis C virus infection. Clin Microbiol Infect. 2005;11(2):86-94.

40. Gonzaga RM, Rodart IF, Reis MG, Ramalho Neto CE, Silva DW. Distribution of Hepatitis C virus (HCV) genotypes in seropositive patients in the state of Alagoas, Brazil. Braz J Microbiol. 2008;39(4):644-7.

41. Ramia S, Eid-Fares J. Distribution of hepatitis C virus genotypes in the Middle East. Int J Infect Dis. 2006;10(4):272-7. 